competition among students in Forestry, Engineering and Architecture on behalf of the F.P.R.S. These were as follows:

\title{
Engineering and Architecture Subjects
}

Etude de la charpente en bois lamellé pour la construction d'une église à Ville Lasalle, Quebec. J. G. Trudeau, Ecole Polytechnique, Montreal. This paper prepared in French with an English summary. Award- $\$ 50.00$.

Design and Performance of the Suction Press on Modern Newsprint Machines. J. W. Smith, Queen's University, Kingston. Award- $\$ 50.00$.

Design of a Prefabricated Plywood Industrial Building. J. D. Hodd and R. F. White. N.S. Technical College, Halifax. Award- $\$ 25.00$.

Forestry Subjects

Bolts-A Factor in the Utilization of Low Quality Hardwoods. J. Johnston, University of Toronto, Toronto. Award- $\$ 25.00$.

\section{ERRATUM}

The volume formula at the bottom of Page 366 (Vol. 31, No. 4) of the December 1955 Forestry Chronicle should read:

Volume $=58.06($ tree height $)+33.46$ (crown diameter $)+40.57$ (crown density) - 2653.

\section{B.C. Registered Foresters}

The Council of the Association of British Columbia Foresters announces that the following candidates have completed the requirements and are now registered to practise forestry under the provisions of the B.C. Foresters Act: Maurice J. Ayers, H. J. Hodgins (Victoria) Ltd., Victoria; Kenneth G. Fensom, Dominion Forest Prod. Lab., U.B.C. Campus, Vancouver; Jack L. Robinson, B.C. Forest Service, Kamloops; Stanley M. Lockard, Vancouver; Peter E. Robson, B.C. Forest Service, Kamloops; John Walters, Research Forester, University Forest, Haney; Tollef Kilde, Rena, Norway; Ryszard Borzuchowski, B.C. Forest Service, Research Div., Victoria; Glen A. Patterson, Canadian Forest Products Ltd., Englewood; Donald T. Grant, B.C. Forest Service, Prince George; Nicholas Novak, Northern Plywoods Ltd., via Vancouver; William V. Lowry, Alaska Pine \& Cellulose Ltd., Vancouver; John F. Joyce, B.C. Forest Service, Nelson; G. G. Anthony Hilliard, Boundary Sawmills Ltd., Midway.

\section{Woodlands Research Director Appointed}

The appointment of Lowell Besley as Chairman of the woodlands research department of the Pulp and Paper Research Institute of Canada in Montreal was announced recently by Dr. Lincoln R. Thiesmeyer, president of the Institute. This appointment will take effect July 1. Mr. Besley was Dean of the Faculty of Forestry of the University of British Columbia. He has served as a director of the Canadian Institute of Forestry and chairman of its Vancouver section; as a director of the Canadian Forestry Association; and as vice-president of the Association of B.C. Foresters. He was born in Baltimore and educated at Cornell University and at Yale University where he received a Master of Forestry degree with distinction in 1931. He has been executivedirector of the American Forestry Association since July 1953. 
Mr. Besley has had some fifteen years of experience on the faculties of Pennsylvannia State College, West Virginia University, Duke University, and the University of British Columbia. In addition, he has held a variety of posts in the U.S. Federal Forestry Service and in State Forest Experiment Stations from New England to the South. In Canada, he was a consultant on industrial forest management problems in the firm of C. D. Shultz and Co. Ltd. of Vancouver.

\section{B.C. Registered Foresters Elect Officers}

The Eighth Annual Meeting of B.C. Registered Foresters was held in the Hotel Georgia, Vancouver on January 27, 1956. Outgoing President John Jacobsen reported that 35 new members registered during the year bringing the total membership to 255 . He announced the following officers elected for 1956:

Kenneth C. McCannel, President (Consulting Forester, Vancouver); John F. Jacobsen, Past-President (Resident Manager, Empire Mills Ltd., Squamish); H. Mickey Pogue, Vice-President (Forester i/c Surveys Division, B.C. Forest Service, Victoria).

Re-elected Members of Council were: George S. Allen, (Dean, Faculty of Forestry, U.B.C.); Walter G. Hughes (Forester, i/c Working Plans Division, B.C. Forest Service, Victoria).

New Members of Council were: W. Gerald Burch (Assistant Forester, B.C. Forest Products Ltd., Vancouver); John W. Ker (Faculty of Forestry, U.B.C., Vancouver); Don McColl (General Wood Manager, Tahsis Co. Ltd., Vancouver); and F. M. Knapp, re-appointed Registrar (Faculty of Forestry, U.B.C., Vancouver).

\section{NEWS FROM OUR ADVERTISERS}

Watson Jack \& Company Limited and F. H. Hopkins \& Company Limited, which have been in the business since 1898 and 1904 respectively, have now combined and will operate under the name of Watson Jack - Hopkins Limited.

For over 50 years they have distributed similar lines of equipment in substantially the same territories. Furthermore, they have both been whollyowned by the B. J. Coghlin Co. Limited, which has been recognized for the past 87 years as one of the country's leading manufacturers of springs, track tools, hydraulic appliances and railway supplies. It will continue to be the parent Company.

Offices and plants are strategically situated throughout Quebec and Ontario. In addition, the Company will manufacture and distribute throughout Canada its WAJAX Fire Fighting equipment.

Watson Jack - Hopkins Limited will continue to represent such well known principles as Bucyrus-Erie power shovels, cranes, drills and railway wrecking cranes; Austin-Western graders, cranes and crushing plants; Jordan railway spreaders, ditchers; Master Vibrator $\mathrm{Co}$. space heaters and concrete equipment; Ohio Locomotive cranes, Owen buckets and grapples; Sauermann scrapers; Vickers-Armstrongs crawler tractors, and a complete line of smaller construction equipment manufacturers. 